\title{
Evidence for B chromosome drive suppression in the grasshopper Eyprepocnemis plorans
}

\author{
J. A. HERRERA, M. D. LÓPEZ-LEÓN, J. CABRERO, M. W. SHAW† \& J. P. M. \\ CAMACHO* \\ Departamento de Genetica, Facultad de Ciencias, Universidad de Granada, E-18071 Granada, Spain and \\ $\dagger$ Department of Agricultural Botany, School of Plant Sciences, University of Reading, Whiteknights, \\ Reading RG6 $2 A U$, U.K.
}

\begin{abstract}
The grasshopper Eyprepocnemis plorans is polymorphic for both a B chromosome and a heterochromatic segment of chromatin on the smallest autosome. Females transmit these to their offspring more frequently after copulating with a male from a population without Bs than after copulating with a male from their own population. Paternity analyses using the heterochromatic segment as a marker showed that the effect of male on female transmission does not depend on fertilization because it occurs even when all the eggs are fertilized by sperm from another mating. The possible mechanisms include behavioural differences in mating and transfer of substances affecting female meiosis in male ejaculate. The data support the idea that the $\mathrm{B}$ chromosome is initially subject to meiotic drive in populations in which it has not previously existed, and that genes which suppress this drive are then selected.
\end{abstract}

Keywords: B chromosomes, drive suppression, Eyprepocnemis plorans, oogenesis, segregation.

\section{Introduction}

Eyprepocnemis plorans is an abundant species along the Mediterranean and south Atlantic coasts of the Iberian Peninsula, where it harbours a very widespread B chromosome polymorphism that is unusual in lacking detectable drive. This makes it hard to explain the origin, establishment and maintenance of the polymorphism (López-León et al., 1992). Drive suppressor genes have been demonstrated in the standard genome of at least two animal species polymorphic for B chromosomes, i.e. Myrmeleotettix maculatus (Shaw \& Hewitt, 1985; Shaw et al., 1985) and Pseudococcus affinis (Nur \& Brett, 1985, 1987, 1988). In addition, genetic control of $B$ transmission has been shown in maize (Carlson, 1969), rye (Romera et al., 1991) and Aegilops speltoides (Cebria et al., 1994). It therefore seemed possible that the B chromosomes of $E$. plorans used to have drive which has been suppressed by the standard genome. The main objective of the present investigation was to test this hypothesis. Our strategy was to perform

${ }^{*}$ Correspondence. between-population crosses, especially between populations with and without Bs. We reasoned that populations without Bs might lack suppressor elements, so that $\mathrm{B}$ drive would be manifest. Remarkably, effects appeared in the parental generations of these crosses, rather than first in the hybrids as might be expected of genes controlling segregation. This implies that the genotype of the male to which a female is mated influences female segregation. We were able to use another polymorphism to show that this effect did not depend on the sperm themselves.

\section{Materials and methods}

We used animals from four populations with B chromosomes (Salobreña, Jete, Fuengirola and Tarragona) and one without (Albacete), collected between September and December for 1990-92. All females used for crosses were collected in the field when they were at the last nymphal instar to ensure virginity. Once adult, the grasshoppers were placed in culture cages to perform controlled crosses in a room regulated at $27^{\circ} \mathrm{C}$ with a $12 \mathrm{~h}$ light: $12 \mathrm{~h}$ dark- 
ness cycle. Cages were cleaned and fresh grass from the field was supplied daily. Once enough embryos had been obtained from a cross, the adults and the embryos were fixed for cytological analysis following methods described elsewhere (López-León et al., 1993). Controlled crosses were performed according to several different procedures: $C_{1}$ to $C_{4}$ were simple crosses of a female from one population to a male from another; in $\mathrm{C}_{5}$ two males from one population were simultaneously allowed access to a female from another population; in $\mathrm{C}_{6}$ to $\mathrm{C}_{17}$ females were mated successively to two different males, the second being allowed access after an egg pod had been laid; and in $\mathrm{C}_{18}$ and $\mathrm{C}_{19}$ females were mated successively to three males, each being allowed access after a pod had been laid. Males were removed after one copulation, other than in cross $\mathrm{C}_{5}$, and the days when eggs were laid were also noted. Males were analysed cytologically before mating by extracting some testis follicles through a small opening between the second and the third abdominal segments. In all crosses except $\mathrm{C}_{10}$ and $\mathrm{C}_{14}$ the female carried $\mathrm{B}$ chromosomes and the males lacked them. Except for the two males in the $\mathrm{C}_{5}$ cross, all males mated once. Methods for cytological analysis were the same as those of López-León et al. (1992).

\section{Results}

Table 1 shows the results of crossing 19 females to one or more males under controlled conditions. It is evident that the transmission ratio of the $\mathrm{B}$ chromosome varies dramatically between egg pods laid by the same female. There is no regular temporal trend in this and the phenomenon is seen in females from both Jete and Salobreña. Although the transmission frequency sometimes varies in pods laid without a further copulation (pods 2 and 3 in $\mathrm{C}_{12}$; pods 1 and 2 in $\mathrm{C}_{18}$ ), the transmission frequency seems to be linked to the particular copulation (e.g. pods 1-4 in $\mathrm{C}_{5}$ or pods $1-3$ in $\mathrm{C}_{19}$ ). That is, the males are one factor influencing the $\mathrm{B}$ transmission ratio through the female. In 2B and $3 \mathrm{~B}$ females, however, all within- and between-population egg pods showed Mendelian transmission ratios (Table 2), so that the male effect was not apparent.

Some females carried a supernumerary heterochromatic segment in the smallest autosome, which served as an additional marker. Previous withinpopulation controlled crosses demonstrated that some females heterozygous (NS) for this marker and possessing $1 \mathrm{~B}$, and all NS females carrying $2 \mathrm{~B}$, transmit the segmented (S) chromosome significantly less often than expected (López-León et al., 1991). In two of the six egg pods laid after mating with a local male, NS females undertransmitted the $\mathrm{S}$ chromosome $\left(\mathrm{C}_{9}\right.$ and $\left.\mathrm{C}_{13}\right)$. In both these cases, however, egg pods laid after mating with a male from the Albacete population showed a Mendelian transmission ratio $\left(k_{\mathrm{s}}\right)$ of this chromosome (Table 1). Hence, supernumerary segment transmission, like that of the $B$, varies between egg pods, and may be influenced by the genotype of the most recently mated male.

The results in the nine females from Salobreña that were crossed to males from both Salobreña and Albacete populations were studied in more detail. The transmission ratios of the B chromosome $\left(k_{\mathrm{B}}\right)$ and the $\mathrm{S}$ chromosome $\left(k_{\mathrm{S}}\right)$ were significantly higher following copulation with an Albacete male than after copulation with a local male (Table 3). This strongly suggests that males can influence female transmission of both chromosomal markers.

The numbers of eggs and embryos per pod produced by these nine females did not differ significantly among the egg pods produced following mating with the males from the two localities (Table 3 ), so there was little differential egg or embryo mortality associated with copulation with an alien male. The figures in Table 3 were very close to those we have observed in naturally mated females from Salobreña laying in the laboratory. Therefore, the altered transmission ratio is not based on differential zygote survival and must result from changes in chromosome behaviour during female meiosis.

It is possible for males to influence chromosome behaviour during meiosis, because in E. plorans female meiotic segregation occurs after copulation. When the eggs are laid, the oocyte is arrested at metaphase I, and meiosis is continued outside the female's body, being completed by about $3-4$ h later (Henriques-Gil et al., 1986). As female meiosis is completed after laying, the spermatozoon has necessarily to be inside the egg when homologous chromosomes separate in anaphase I. This suggests that the effects might be produced by sperm postmeiotic gene expression. This hypothesis can be tested using the supernumerary segment polymorphism in males to determine which sperm fertilized the egg. Three crosses are suitable for this purpose. In the $\mathrm{C}_{8}$ cross, the first mating was to a foreign $\mathrm{NN}$ male; Bs accumulated. The second mating was to a local SS male. The transmission ratio in the second pod was Mendelian; however, all 24 embryos analysed were $\mathrm{NN}$ and were therefore fertilized by the sperm of the first male. In both $C_{14}$ and $C_{19}$ crosses, one of the males used was heterozygous for the supernumerary segment, so inferences are 


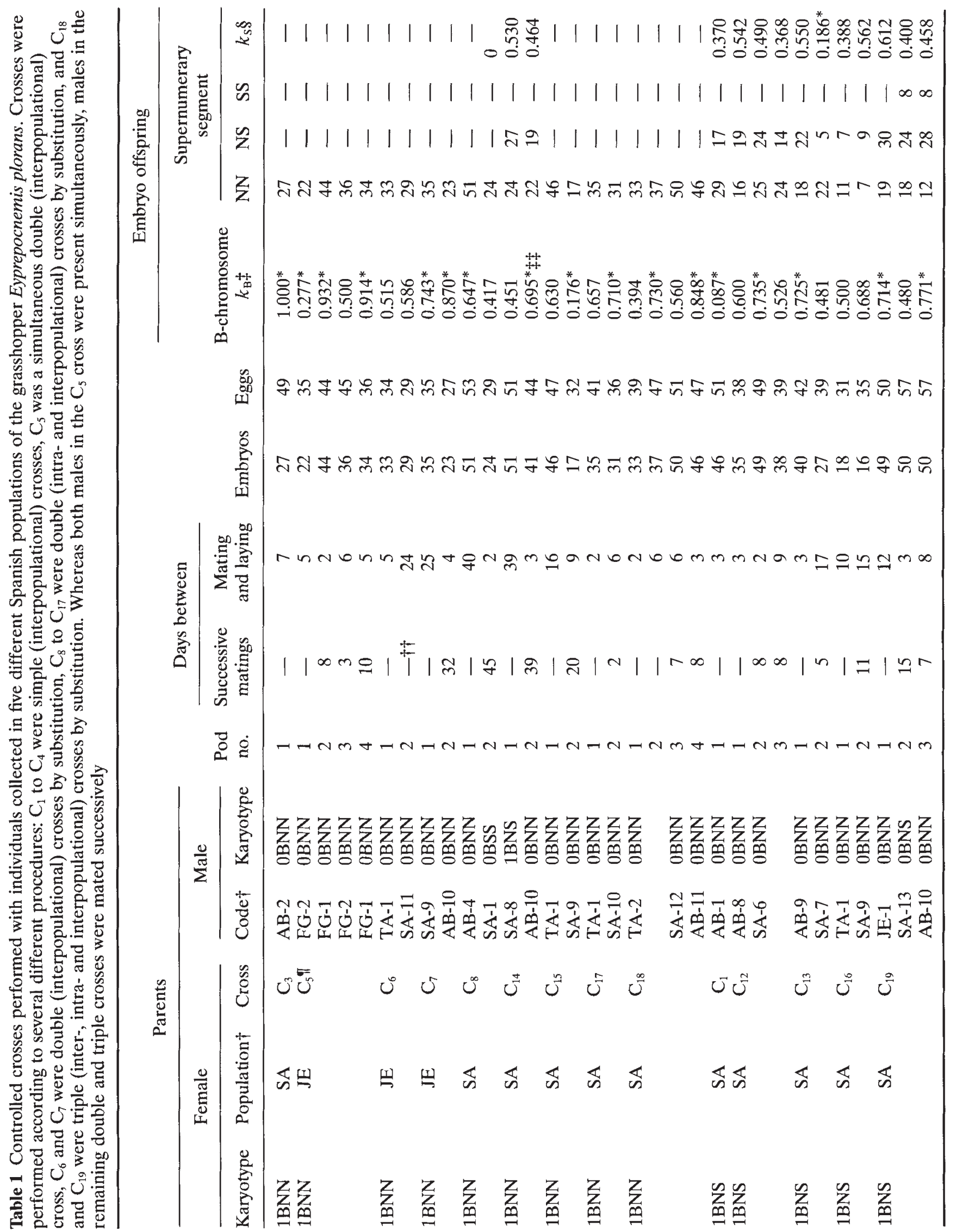

(C) The Genetical Society of Great Britain, Heredity, 76, 633-639. 


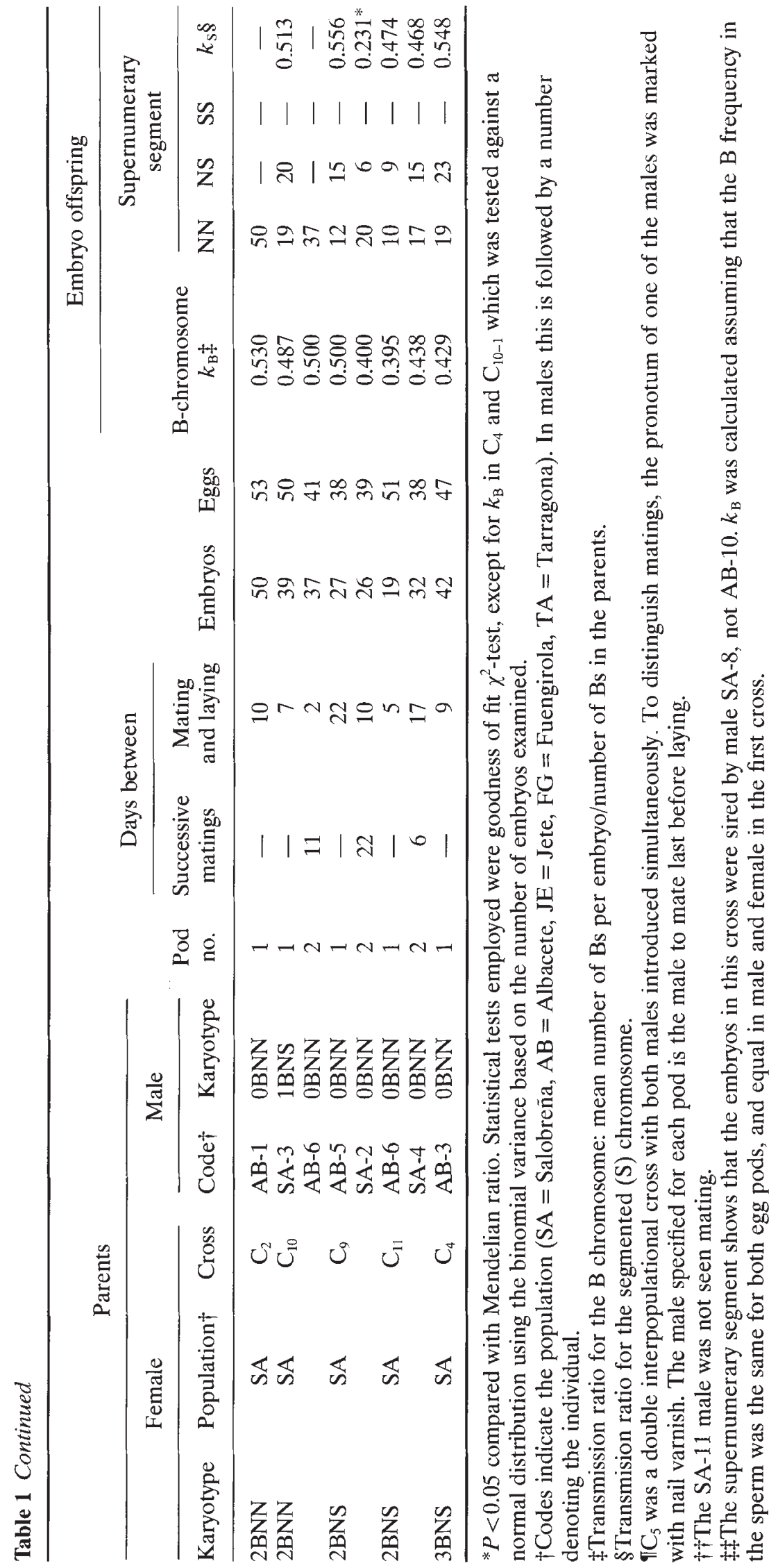

(C) The Genetical Society of Great Britain, Heredity, 76, 633-639. 
Table 2 A summary of B chromosome transmission in the 36 crosses of Eyprepochemis plorans

\begin{tabular}{llccc}
\hline \multirow{2}{*}{$\begin{array}{l}\text { No. Bs in } \\
\text { female }\end{array}$} & Type of cross & \multicolumn{3}{c}{ Type of B transmission ratio (no. crosses) } \\
\cline { 3 - 5 } & Elimination & Mendelian & Accumulation \\
\hline 1B & Within-population & 1 & 6 & 2 \\
& Between-population & 2 & 6 & 11 \\
$2 \mathrm{~B} \dagger$ & Within-population & 0 & 3 & 0 \\
& Between-population & 0 & 5 & 0 \\
\hline
\end{tabular}

tOne of these crosses involved a 3B female.

Table 3 Comparison of clutch size and transmission ratios for the B chromosome $\left(k_{\mathrm{B}}\right)$ and the supernumerary segment $\left(k_{\mathrm{S}}\right)$ in nine Salobreña females each crossed to a male from the same population (within-population crosses) and to a male from the non-B population (between-population crosses)

\begin{tabular}{|c|c|c|c|c|c|c|}
\hline \multirow[b]{2}{*}{ Item } & \multicolumn{3}{|c|}{$\begin{array}{l}\text { Within-population } \\
\text { crosses }\end{array}$} & \multicolumn{3}{|c|}{$\begin{array}{l}\text { Between-population } \\
\text { crosses }\end{array}$} \\
\hline & Mean & SE & $n$ & Mean & $\mathrm{SE}$ & $n$ \\
\hline Eggs per pod & 44.20 & 2.90 & 9 & 45.70 & 2.30 & 9 \\
\hline Embryos per pod & 38.10 & 3.70 & 9 & 38.40 & 3.50 & 9 \\
\hline Embryos/eggs & 0.85 & 0.04 & 9 & 0.85 & 0.06 & 9 \\
\hline$k_{\mathrm{B}}$ & 0.48 & 0.02 & 9 & $0.63^{*}$ & 0.05 & 9 \\
\hline$k_{\mathrm{S}}$ & 0.34 & 0.06 & 5 & $0.52^{*}$ & 0.02 & 5 \\
\hline
\end{tabular}

${ }^{*} P<0.05$ (paired $t$-test) compared with corresponding data for withinpopulation crosses.

weaker and must be based on the $\mathrm{N}: \mathrm{S}$ ratio of the offspring. In the second pod of the $\mathrm{C}_{14}$ cross and the third pod of the $\mathrm{C}_{19}$ cross, eggs had an excess of $\mathrm{B}$ chromosomes following copulation with a foreign male, even though the sperm from this foreign male did not fertilize enough to disturb the ratio of NN:NS embryos (see Table 1).

\section{Discussion}

The fact that foreign male effects are only detectable on $1 \mathrm{~B}$ females, and not on $2 \mathrm{~B}$ and $3 \mathrm{~B}$ ones, in which a large proportion of the Bs form bivalents, suggests that they depend on the presence of $\mathrm{B}$ univalents in metaphase I, and most likely act on the first meiotic division where 75 per cent of B univalents in 1B females divide reductionally (LópezLeón et al., 1992). Thus preferential migration of B univalents (to the secondary oocyte in cases of B accumulation or to the first polar body in cases of $\mathrm{B}$ elimination) could explain the observed male effects. In the case of the supernumerary segment system, the male effects determine that $\mathrm{N}$ and $\mathrm{S}$ chromosomes migrate randomly becoming independent of the presence of B chromosomes.

It is possible that the effects need a minimum time between mating and laying to become apparent. This is suggested by the $C_{18}$ and $C_{12}$ crosses. In $\mathrm{C}_{18}$ the first mating was to a foreign male. The $\mathrm{B}$ transmission ratio in the first egg pod (laid two days after mating, see Table 1) was Mendelian, but there was accumulation in the second, laid six days after mating. In the $\mathrm{C}_{12}$ cross, the $\mathrm{B}$ transmission ratio was Mendelian in the first egg pod, laid only three days after mating with a foreign male. However, the next pod, laid two days after mating with a local male, showed $\mathrm{B}$ accumulation $\left(k_{\mathrm{B}}=0.74\right)$. An additional pod, laid nine days after mating with the local male, showed the $k_{\mathrm{B}}$ expected from a within-population cross $(0.53)$. In the $C_{13}$ cross, however, the $B$ accumulated in a pod laid only three days after mating with a foreign male. It is possible, therefore, that the minimum time for effects is between two and three days. 
The effects of the male on chromosome segregation in the female appear to be dependent on copulation but independent of fertilization. A possible explanation is that they are produced by some substance(s) contained in the ejaculate. It is known that males of many insects contribute proteinaceous nutrients with the ejaculate (Markow \& Ankney, 1984; Pitnick et al., 1991). We have recently observed transfer of nutrients from ejaculate into eggs of E. plorans using radioactive labelling (Pardo et al., 1995). Interestingly, transfer of nutrients from ejaculate was low in eggs from pods laid promptly after mating but high in subsequent pods, which clearly supports the existence of a minimum time for male effects on female meiotic segregation.

Insect ejaculate contains a variety of substances, mainly produced in the accessory gland, that influence female reproductive behaviour and physiology (Leopold, 1976; Gromko et al., 1984). As examples, we may mention an anti-aphrodisiac pheromone (Jallon et al., 1981), or the enzyme esterase-6, which influences the time until a female remates, the rate of sperm usage, productivity, copulation duration and pairing rate (Richmond et al., 1980; Gilbert et al., 1981; Gilbert \& Richmond, 1982a,b). Another enzyme, glucose oxidase, may function as a bactericide and fungicide (Cavener, 1980), and other substances stimulate oviposition (Baumann, 1974a,b). Perhaps the most interesting ejaculate component, however, bearing in mind that male effects are exerted on chromosome behaviour during the first meiotic division in the female, was found in Drosophila, i.e. a series of filamentous structures with a size and morphology identical to the microtubules (Bairati, 1966; Perotti, 1971). The function of microtubules in the seminal fluid is completely unknown, although some authors have suggested that they could help sperm to move toward storage organs (Bairati, 1966), or that they could serve as a sperm nutrient during storage (Perotti, 1971).

In looking for a cause of male effects on female meiotic segregation, perhaps microtubule proteins might regularly be transferred from males and used in female meiosis. Interestingly, it has recently been demonstrated that in the apical diverticulum of the $E$. plorans spermatheca there is a progressive dismantling of the sperm flagellum, so that accessory tubules separate from the axoneme and the microtubule doublets scatter throughout the cytoplasm and depolymerize (Longo et al., 1993). This might constitute a source for microtubule components entering the eggs and influencing meiotic segregation in the oocytes which, when the eggs are laid, are arrested at metaphase I (Henriques-Gil et al., 1986).
Paternal contribution of microtubules has been described in ferns, in which it was reported to be important in growth and development (Bell, 1979). This kind of contribution could also be an explanation for male effects on the rate of cleavage of zygotes resulting from inter-strain crosses, observed a long time ago in rabbits (Castle \& Gregory, 1929; Gregory \& Castle, 1931; Castle, 1941).

Finally, we would like to comment on the implications the present results have for the population biology of B chromosomes in E. plorans, which was our initial objective. Crosses between populations demonstrate that these $\mathrm{B}$ chromosomes can be driven in matings with males from populations without Bs. This suggests the existence of genes suppressing drive in the genome of populations possessing Bs. These genes could act by influencing the amount of male-derived microtubule components entering the eggs. The fact that most males from the non-B population induce accumulation of Bs suggests that these suppressor genes are scarce in this population. This would be expected if Bs have never been present in this population, or they have been absent for a long time period. We suggest the hypothesis that $\mathrm{B}$ chromosomes in $E$. plorans possessed drive when they originated, allowing the present widespread polymorphism to be established, but that this drive has now been suppressed by the host genome. This is consistent with the standard selfish theory about B chromosomes (Shaw \& Hewitt, 1990), but E. plorans is a very dramatic example of the coevolution of A and B chromosomes.

\section{Acknowledgements}

This study was partially supported by grants from the Dirección General de Investigación Científica y Técnica (no. PB93-1108) and the Plan Andaluz de Investigación, Grupo no. 3122 (Spain).

\section{References}

BAIRAT1, A. 1966. Filamentous structures in spermatic fluid of Drosophila melanogaster Meig. J. Microscopy, 5, 265-268.

BAUMANN, H. 1974a. The isolation, partial characterization and biosynthesis of the paragonial substances, PS-1 and PS-2, of Drosophila funebris. J. Insect Physiol., 20, 2181-2194.

BAUMANN, H. 1974b. Biological effects of paragonial substances PS-1 and PS-2, in females of Drosophila funebris. J. Insect Physiol., 20, 2347-2362.

BELL, P. R. 1979. The contribution of the ferns to an understanding of the life cycles of vascular plants. In: 
Dyer, A. F. (ed.) The Experimental Biology of Ferns, pp. 58-85. Academic Press, New York.

CARLSON, w. 1969. Factors affecting preferential fertilization in maize. Genetics, 62, 543-554.

Castle, w. E. 1941. Size inheritance. Am. Nat., 75, 488-498.

CASTLE, W.E. AND GREGORY, P. w. 1929. The embryological basis of size inheritance in the rabbit. J. Morphol., 48, 81-104.

CAVENER, D. R. 1980. The genetics of male specific glucose oxidase and the identification of other unusual hexose enzymes in Drosophila melanogaster. Biochem. Genet., 18, 929-937.

CEBria, A., NAVARRO, M. L. AND pUERTAS, M. J. 1994 Genetic control of B chromosome transmission in Aegilops speltoides (Poaceae). Am. J. Bot., 81, 1502-1507.

GILBERT, D. G. AND RICHMOND, R. C. 1982a. Esterase 6 in Drosophila melanogaster: Reproductive function of active and null males at low temperature. Proc. Natl. Acad. Sci. U.S.A., 79, 2962-2966.

GILBERT, D. G. AND RICHMOND, R. C. 1982b. Studies of esterase 6 in Drosophila melanogaster XII. Evidence for temperature selection of Est 6 and Adh alleles. Genetica, 58, 109-119.

GILBERT, D. G., RICHMOND, R. C. AND SHEEHAN, K. B. 1981 Studies of esterase 6 in Drosophila melanogaster. V. Progeny production and sperm use in females inseminated by males having active or null alleles. Evolution, 35, 21-37.

GREGORY, P. W. AND CASTLE, W. E. 1931. Further studies on the embryological basis of size inheritance in the rabbit. J. Exp. Zool., 59, 199-211.

GROMKO, M. H., GILBERT, D. G. AND RICHMOND, R. C. 1984. Sperm transfer and use in the multiple mating system of Drosophila. In: Smith, R. L. (ed.) Sperm Competition and the Evolution of Animal Mating Systems, pp. 371-426. Academic Press, New York.

HENRIQUES-GIL, N., JONES, G. H., CANO, M. 1., ARANA, P. AND SANTOS, J. L. 1986. Female meiosis during oocyte maturation in Eyprepocnemis plorans (Orthoptera: Acrididae). Can. J. Genet. Cytol., 28, 84-87.

JALLON, J. M., ANTHONY, C. AND BENAMAR, o. 1981. Un anti-aphrodisiaque produit par les males de Drosophila melanogaster et transfer aux femelles los de la copulation. C. r. Acad. Sci. Paris, 292, 1147-1149.

LEOPOLD, R. A. 1976. The role of male accessory glands in insect reproduction. Ann. Rev. Ent., 21, 199-221.

LONGO, G., SOTTILE, L., VISCUSO, R., GIUFFRIDA, A. AND PRIVITERA, R. 1993. Ultrastructural changes in sperm of Eyprepocnemis plorans (Charpentier) (Orthoptera: Acrididae) during storage of gametes in female genital tract. Invert. Reprod. Dev., 24, 1-6.

LÓPEZ-LEÓN, M. D., CABRERO, J. AND CAMACHO, J. P. M. 1991. Meiotic drive against an autosomal super- numerary segment promoted by the presence of a B chromosome in females of the grasshopper Eyprepocnemis plorans. Chromosoma, 100, 282-287.

LÓPEZ-LEÓN, M. D., CABRERO, J., CAMACHO, J. P. M., CANO, M. 1. AND SANTOS, J. L. 1992. A widespread B chromosome polymorphism maintained without apparent drive. Evolution, 46, 529-539.

López-lé́n, M. D., CABrero, J., PARdo, M. C., VISERAS, E. AND CAMACHO, J. P. M. 1993. Paternity displacement in the grasshopper Eyprepocnemis plorans. Heredity, 71, 539-545.

MARKOW, T.A. AND ANKNeY, P. F. 1984. Drosophila males contribute to oogenesis in a multiple mating species. Science, 224, 302-303.

NUR, U. AND BRETT, B. L. H. 1985. Genotypes suppressing meiotic drive of a B chromosome in the mealybug Pseudococcus obscurus. Genetics, 110, 73-92.

NUR, U. AND BRETT, B. L. H. 1987. Control of meiotic drive of $\mathrm{B}$ chromosomes in the mealybug Pseudoccoccus affinis (obscurus). Genetics, 115, 499-510.

NUR, U. AND BRETT, B. L. H. 1988. Genotypes affecting the condensation and transmission of heterocromatic B chromosomes in the mealybug Pseudoccocus affinis. Chromosoma, 96, 205-212.

PARDO, M. C., LÓPEZ-LEÓN, M. D., HEWITT, G. M. AND CAMACHO, J. P. M. 1995. Female fitness is increased by frequent mating in grasshoppers. Heredity, 74, 654-660.

PEROTTI, M. E. 1971. Microtubules as components of Drosophila male paragonia secretion: An electron microscope study with enzymatic test. J. Submicro. Cytol., 3, 255-282.

PITNICK, S., MARKOW, T. A. AND RIEDY, M. F. 1991. Transfer of ejaculate and incorporation of male-derived substances by females in the nannoptera species group (Diptera: Drosophilidae). Evolution, 45, 774-780.

RICHMOND, R. C., GILBERT, D. G., SHEEHAN, K. B., GROMKO, M. H. AND BUTTERWORTH, F. M. 1980. Esterase 6 and reproduction in Drosophila melanogaster. Science, 207, 1483-1485.

ROMERA, F., JIMÉNEZ, M. M. AND PUERTAS, M. J. 1991. Genetic control of the rate of transmission of rye $B$ chromosomes. I. Effects in $2 \mathrm{~B} \times 0 \mathrm{~B}$ crosses. Heredity, 66, 61-65.

SHAW, M. W. AND HEwITT, G. M. 1985. The genetic control of meiotic drive acting on the B chromosome of Myrmeleotettix maculatus (Orthoptera: Acrididae). Heredity, 54, 187-194.

SHAW, M. W. AND HEWITT, G. M. 1990. B chromosomes, selfish DNA and theoretical models: where next? Oxford Surv. Evol. Biol., 7, 197-223.

SHAW, M. W., HEWITT, G. M. AND ANDERSON, D. A. 1985. Polymorphism in the rate of meiotic drive acting on the B chromosome of Myrmeleotettix maculatus. Heredity, $\mathbf{5 5}, 61-68$. 